\title{
ANÁLISE DE CONFORTO TÉRMICO ASSOCIADO A UMA COZINHA DE RESTAURANTE UNIVERSITÁRIO
}

\author{
IARA FERREIRA DE REZENDE COSTA, M.SC. |UFVJM \\ CAROLINE FERREIRA| UFVJM \\ ALCINO DE OLIVEIRA COSTA NETO, M.SC. | UFVJM
}

O objetivo primordial dos estudos em conforto térmico é o de determinar as condições imprescindíveis para a avaliação do adequado ambiente térmico, capaz de proporcionar a satisfação e bem estar ao homem.

Diante do exposto, o presente trabalho apresenta a avaliação do desempenho térmico da cozinha do Restaurante Universitário (RU) localizado no campus da Universidade Federal dos Vales do Jequitinhonha e Mucuri (UFVJM), no município de Teófilo Otoni, utilizando o programa Conforto MAIS (Silva, 2018), elaborado a partir do método Centre Scientifique et Technique du Batiment (CSTB) e desenvolvido na UFVJM com a linguagem JAVA.

No programa Conforto MAIS, as fachadas são divididas em Fachada 01, 02, 03 e 04, sendo primordial a escolha da fachada real correspondente aquela para a simulação. Para o estudo, apenas uma fachada é considerada, sendo esta a Fachada 01 (Figura 1), correspondente à face nordeste (NO), pois apenas a mesma estará em contato com a envoltória externa da edificação.

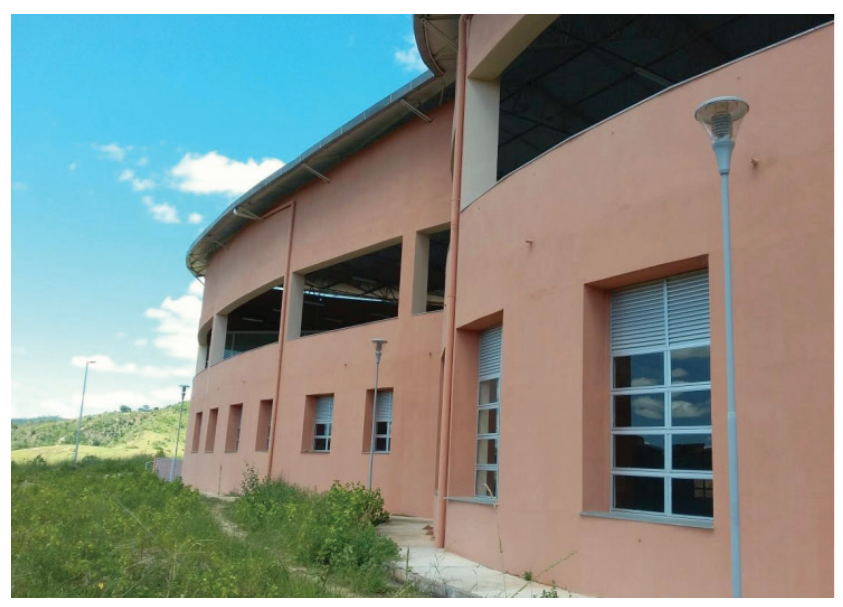

Figura 1 - Fachada noroeste do Restaurante Universitário Fonte: Autores

Outra observação é que, por se tratar de um edifício que possui dois andares, e a cozinha estar situada no térreo, não serão considerados os ganhos de calor através da cobertura.
Para o programa funcionar, é necessário preencher todas as entradas. As informações necessárias são: valor da incidência solar, tipos de materiais na alvenaria, cobertura e piso, espessura desses elementos, a potência dissipada pelos equipamentos e pessoas na cozinha, assim como o número de trocas de ar. Em relação as três fachadas localizadas no interior da edificação, foram adotados valores similares à fachada que recebe a incidência solar. $\mathrm{O}$ diferencial quanto às mesmas é o valor zero preenchido nos campos de incidência solar (lg). Quanto aos isolantes térmicos, foi adotado a espessura zero para as quatro fachadas.

Após a adição de todos os dados requeridos pelo programa, este expôs os resultados da temperatura interna máxima. O resultado exibido pela aplicação é apresentado na Figura 2.

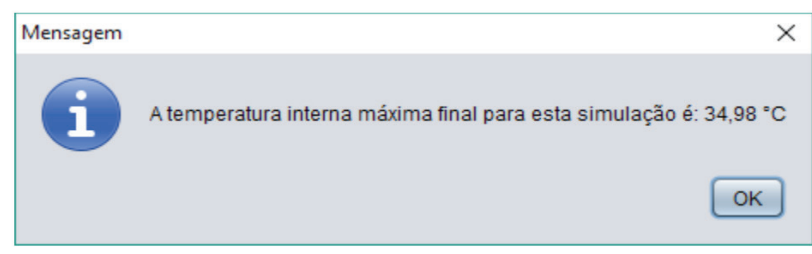

Figura 2 - Resultado da temperatura interna máxima Fonte: Autores

Considerando os resultados da avaliação do desempenho térmico, pôde-se concluir que a cozinha da edificação não se encontra em condições de conforto. Esse resultado expressa o fato de se tratar de um ambiente cujas atividades ali realizadas somadas à geração de calor devido os equipamentos utilizados e as altas temperaturas de cozimento dos alimentos levarem o local a se encontrar em uma zona de estresse térmico.

A ventilação cruzada destaca-se como alternativa para o ambiente, aprimorando a ventilação local, a fim de se evitar a utilização de climatizadores de ar, por ser uma opção energeticamente não sustentável. Outras forma de melhorar o conforto da cozinha seria sombrear as aberturas como forma de diminuir a entrada do calor externo à edificação. 
Análise de conforto térmico associado a uma cozinha de restaurante universitário

I. F. de R. Costa, C. Ferreira \& A. de 0. Costa Neto

\section{REFERÊNCIAS}

SILVA, D. T. Desenvolvimento de um programa para avaliação do desempenho térmico aplicando o método C.S.T.B. Estudo de caso: ginásio poliesportivo da UFVJM Campus Mucuri. 2018. Trabalho de conclusão de curso (Bacharelado em Engenharia Civil) - Universidade Federal dos Vales do Jequitinhonha $\mathrm{E}$ Mucuri, Teófilo Otoni, 2018 